\title{
TANDEM-X: SCIENCE ACTIVITIES
}

\author{
Irena Hajnsek ${ }^{1,2}$ and Thomas Busche ${ }^{1}$ \\ 1 German Aerospace Center - Microwaves and Radar Institute, Wessling, Germany \\ 2 ETH Zurich - Institute of Environmental Engineering, Zurich, Switzerland
}

\begin{abstract}
In this overview the science activities of the TanDEM-X satellite mission are presented and an update on the proposal submission is given.
\end{abstract}

\section{TANDEM-X MISSION}

TanDEM-X (TerraSAR-X add-on for Digital Elevation Measurement) is successfully operating now already since 2010 and has opened a new era in spaceborne radar remote sensing. A single-pass SARinterferometer with adjustable baselines in across- and in along-track directions is formed by adding a second (TDX), almost identical spacecraft to TerraSAR-X (TSX) and flying the two satellites in a closely controlled formation. TDX has SAR system parameters which are fully compatible with TSX, allowing not only independent operation from TSX in a mono-static mode, but also synchronized operation (e.g. in a bi-static mode). With typical across-track baselines of 200-600 m DEMs with a spatial resolution of $12 \mathrm{~m}$ and relative vertical accuracy of $2 \mathrm{~m}$ has been generated. The Helix concept provides a save solution for the close formation flight by combining a vertical separation of the two satellites over the poles with adjustable horizontal baselines at the ascending/descending node crossings.

Beyond the generation of a global TanDEM-X DEM as the primary mission goal, applications based on Cross-track as well as Along-Track Interferometry (ATI) are important secondary mission objectives. Furthermore, TanDEM-X supports the demonstration and application of new SAR techniques, with focus on multi-static SAR, polarimetric SAR interferometry, digital beam forming and super resolution.

The science proposal submission for data requests (CoSSC proposal) is still available through the TanDEM-X Science Service System (https://tandemxscience.dlr.de/) following the basic structure of the TerraSAR-X Science Service System. Some additional features were implemented to alleviate the handling and the use of the web-based interface. The main difference is the procedure for the data ordering. TanDEM-X is following a systematic data acquisition. The main reason for this was its high requirement on the DEM performance and this provides minor flexibility to other mission configurations for science proposals during a specific time. As the main data acquisition for the TanDEM-X DEM was completed, the mission aims to acquire still systematically DEM data in a global scale for a global change layer. This 
means the science data takes have been placed and are still placed in the gaps left by the systematic DEM acquisitions for the change layer. For a controlled handling the scientists cannot order the data takes autonomously for a specific date as in the case of TerraSAR-X, but the science coordination is trying to place the science requests on best effort basis according to the best possible acquisition timeline and satellite resources. Data takes over individual test sites can be requested via science proposal in bistatic as well as in alternating bistatic configuration, the pursuit monostatic mode is not available in 2018 and 2019. The supported imaging modes are Stripmap and all Spotlight modes (except Staring Spotlight) in Single and Dual pol configurations. The alternating bistatic mode is available in single pol configuration only. The ScanSAR imaging mode is not supported. The ATI as well as the Quadpol mode is not available in 2018 and 2019, because the Dual Receive (DRA) mode has been disabled for both satellites. The helix configuration has been changed by a swap of the two satellites in September 2017. DEM acquisition activities are in the Northern hemisphere performed in descending orbits, and for the Southern hemisphere in ascending orbits. The available cross track baselines are in the range of the first two mission years (roughly between 150 and $300 \mathrm{~m})$. Interferometric applications, where a cross track baseline is needed (e.g. for local DEMs or forest height estimation) should follow this strategy as well, especially if the test site is located in higher latitudes (North of $+30^{\circ}$, or South of $-30^{\circ}$ )

\section{DIGITAL ELEVATION MODEL PRODUCTS}

The standard TanDEM-X DEM with 0.4 arcseconds $(\sim 12 \mathrm{~m})$ pixel spacing is a product derived from multiple TanDEM-X acquisitions (minimum two and for difficult terrain up to 8 additional acquisitions also from different viewing angles) and is since September 2016 available via science proposal for the global land masses, including Antarctica and the land masses North of $60^{\circ}$. The specification of the DEM products is given in Table 1. Additionally, standard TanDEM-X DEM product variants are or will be available with a larger pixel spacing, and with a pixel spacing of 1 arcseconds $(30 \mathrm{~m})$, and 3 arcseconds $(90 \mathrm{~m})$ respectively. The $12 \mathrm{~m}$ and $30 \mathrm{~m}$ TanDEM-X DEM products are still available for scientific purposes and can be requested via science proposal on a regional scale at the Science Service System. During 2018 it is planned to improve single DEM tiles, which have been published in 2016 with data gaps. The High Resolution DEM (HDEM) program was cancelled completely and substituted by the change DEM layer program

The 90m TanDEM-X DEM product is in the moment prepared to available by simple FTP download procedures, similar to SRTM DEM download,without any quota restrictions. No proposal will be needed, and the access will be simplified to a simple user registration. The specs and more details on the DEM change layer areplanned to be published in 2018. 


\begin{tabular}{|l|c|c|c|c|}
\hline DEM Product & $\begin{array}{c}\text { Spatial } \\
\text { Resolution } \\
\text { Absolute }\end{array}$ & $\begin{array}{c}\text { Horizontal } \\
\text { Accuracy CE90 }\end{array}$ & $\begin{array}{c}\text { Absolute Vertical } \\
\text { Accuracy LE90 }\end{array}$ & $\begin{array}{c}\text { Relative Vertical } \\
\text { Accuracy }\end{array}$ \\
\hline $\begin{array}{l}\text { TanDEM-X DEM } \\
\text { (standard } \\
\text { product } 0.4 \\
\text { arcsec) }\end{array}$ & $\begin{array}{c}\sim 12 \mathrm{~m} \\
(0.4 \text { arcsec } \\
\text { @ equator) }\end{array}$ & $<10 \mathrm{~m}$ & $<10 \mathrm{~m}$ & $\begin{array}{c}<2 \mathrm{~m} \text { (slope @ 20\%) } \\
<4 \mathrm{~m} \text { (slope }>20 \%) \\
\begin{array}{l}90 \% \text { linear point-to- } \\
\text { point error within an } \\
\text { area of } 1{ }^{\circ} \times 1^{\circ}\end{array}\end{array}$ \\
\hline $\begin{array}{l}\text { TanDEM-X DEM } \\
(1 \text { arcsec) }\end{array}$ & $\begin{array}{c}-30 \mathrm{~m} \\
(1 \text { arcsec } \\
\text { @ equator) } \\
-90 \mathrm{~m}\end{array}$ & $<10 \mathrm{~m}$ & $<10 \mathrm{~m}$ & Not specified \\
\hline $\begin{array}{l}\text { TanDEM-X DEM } \\
(3 \text { arcsec } \\
\text { @ equator) }\end{array}$ & $<10 \mathrm{~m}$ & $<10 \mathrm{~m}$ & Not specified \\
\hline
\end{tabular}

Table 1. TanDEM-X DEM specification table

\section{SUMMARY}

The paper is summarizing the activities of the TanDEM-X science team during 2017-2018.

\section{REFERENCES}

[1] Krieger, Gerhard und Hajnsek, Irena und Papathanassiou, Konstantinos und Younis, Marwan und Moreira, Alberto (2010) Interferometric Synthetic Aperture Radar (SAR) Missions Employing Formation Flying. Proceedings of the IEEE, 98 (5), Pages 816843

[2] Krieger, Gerhard und Moreira, Alberto und Fiedler, Hauke und Hajnsek, Irena und Werner, Marian und Younis, Marwan und Zink, Manfred (2007) TanDEM-X: A Satellite Formation for High Resolution SAR Interferometry. IEEE Transactions on Geoscience and Remote Sensing, 45 (11) , Pages 3317-3341

[3] M. Zink, M. Bachmann, B. Brautigam, T. Fritz, I. Hajnsek, A. Moreira, et al., TanDEM-X: The New Global DEM Takes Shape, Geoscience and Remote Sensing Magazine, IEEE, vol. 2, pp. 8-23, 2014. 